\title{
Capital Abundance and Its Consequences for Trade Policy
}

In the year 2015, private wealth in the area consisting of all OECD member states plus China (accounting for nearly three billion inhabitants) amounted to more than 13 times the level of annual private and public consumption. ${ }^{1}$ Of these 13 consumption years, more than six years are in the form of net public debt. The remaining seven years are real capital (buildings, machines and inventory) and land, the latter mainly urban land. Put differently, real capital accounts for one-third, land amounts to one-fifth and net public debt constitutes almost half of private wealth.

Private wealth owned by corporations is included in our estimate and it is allocated proportionately to shareholders. This is the reason that we do not include shares in firms. We follow the World Inequality Database (WID) approach of integrating Tobin- $Q$ values into the estimate of real capital. ${ }^{2}$ The total wealth estimate may be revised upon receipt of more reliable aggregate statistics of implicit Tobin- $Q$ values for firms, which are not traded on the stock market.

The largest components of private wealth in the form of net public debt are future pensions to be paid by the social security system and future pension rights of public employees. Altogether, they amount to one-third of total private wealth and are therefore similar in size to the level of private real capital.

For our estimate, we assume a risk-free real rate of return of zero. Because the official national accounts and the WID using these accounts work with risk-free real rates of return different from zero, we developed certain extrapolation techniques to come up with our zero rate of interest estimate.

(C) The Author(s) 2019. Open Access: This article is distributed under the terms of the Creative Commons Attribution 4.0 International License (http://creativecommons.org/licenses/by/4.0/), which permits unrestricted use, distribution, and reproduction in any medium, provided you give appropriate credit to the original author(s) and the source, provide a link to the Creative Commons license, and indicate if changes were made.

* Acknowledgement: Open access funding provided by Max Planck Society.

1 See C.C. von Weizsäcker, H. Krämer: Sparen und Investieren im 21. Jahrhundert - Die Große Divergenz, 2019, Springer-Gabler.

2 World Inequality Database, https//wid.world.

Carl Christian von Weizsäcker, Max Planck Institute for Research on Collective Goods, Bonn, Germany.

\author{
Why a zero real rate of interest?
}

There are two reasons to obtain private wealth estimates at a risk-free real interest rate of zero. The first one is obvious: the real risk-free rate of interest actually is zero - at least for the eurozone, Japan and China. The other reason is our contention that the 'natural rate of interest' is negative.

Our definition of the natural rate of interest is motivated by our theoretical reference to traditional capital theory. Could capital theory help to understand what is going on in today's capital markets, and, generally, in today's world economy? Is the theory of 'secular stagnation' an appropriate description of the present situation? Capital theory traditionally worked in a model without public debt. It was Böhm-Bawerk's contention that in a general equilibrium without public debt, the real rate of interest needed to be positive in order to equilibrate capital supply and capital demand. ${ }^{3}$ Our definition then is thus that the natural rate of interest is the hypothetical real rate of interest which would provide full employment in a closed economy with zero net public debt.

To prove our contention of a negative natural rate of interest, we looked at the level of public debt at the lowest non-negative risk-free real rate of return on capital, i.e. at the risk-free real rate of interest of zero. If, in a general equilibrium with a zero real rate of interest, public debt is quite substantial, then the natural rate of interest must be negative.

Alternatively, one could try to obtain a direct estimate of the natural rate of interest. However, we believe that this is close to impossible and therefore refrain from estimating the natural rate of interest. Yet, our numerical results for a zero real rate of interest make us very confident that the natural rate of interest is negative.

\section{The theory explaining the results: The 'meta-model'}

The 'meta-model' developed by the author is much more general than typical macroeconomic models and based on eight assumptions. ${ }^{4}$ Apart from certain continuity properties, the two main assumptions are: firstly, the risk-free rate

3 E. von Böhm-Bawerk: Kapital und Kapitalzins, Zweite Abteilung: Positive des Kapitales, Jena 1889.

4 For the basic philosophy behind this paper, see C.C. von Weizsäcker: Capital Theory of the Steady State; or: $T=Z-D$, April 2019, available at https://www.coll.mpg.de/Weizsaecker/CapitalTheory2019. We only investigate the steady state solutions of the metamodel. If one wanted to investigate the dynamics of an economy, one would have to specify the model further. 
of interest $r$ is an unbiased price signal for intertemporal decisions in the production system (assumption 4) and in the consumption system (assumption 6). Secondly, in the comparison of different steady states, the meta-model satisfies a macroeconomic 'law of demand' in the production system (assumption 5) and in the consumption system (assumption 8). Assumptions 2 and 7 mean that we restrict our metamodel to steady states. Assumptions 1 and 3 specify the continuity properties of the meta-model.

We then can derive two forms of Generalised Golden Rules of Accumulation:

- Theorem 1 is a generalised Phelps-Weizsäcker Golden Rule of Accumulation: in the meta-model steady state, consumption per head is maximised if the risk-free rate of interest $r$ equals the rate of growth $g$. The meta-model is a generalised overlapping generations model.

- Theorem 2 is a generalised Samuelson Golden Rule of Accumulation: in the comparison of different steady states, lifetime utility is maximised at the rate of interest equal to the rate of growth. ${ }^{5}$

The generality of the meta-model must be emphasised. With the exception of the risk-free rate of interest, prices do not have to be correct price signals. Prices may be distorted by monopoly, oligopoly, price fixing, disregard of externalities (positive or negative), government intervention (e.g. rent control), taxes etc. All these price distortions follow the rule that they do not distort the price signal $r{ }^{6}$ The assumption of an undistorted price signal $r$ is just the starting point for an investigation of the long-run growth process. With $r$ being a distorted price signal, the two Golden Rules mentioned above would have to be modified accordingly in order to compensate for the distortion. However, Golden Rules still exist.

\section{No trend in the capital-output ratio}

Modern neoclassical growth theory considers real capital to be an important input variable. The mainstream has used the Solow production function as a convenient approximation for the highly complex production system of a modern economy. ${ }^{7}$ But are there limits for the substitution between labour

5 For a special case of Theorem 2, see P.A. Samuelson: An Exact Consumption Loan Model of Interest with or without the Social Contrivance of Money, in: Journal of Political Economy, Vol. 66, No. 6, 1958, pp. 467-482.

6 One could also accommodate distortions of the price signal $r$, as shown in C.C. von Weizsäcker, op. cit.

7 R. Solow: A Contribution to the Theory of Economic Growth, in: Quarterly Journal of Economics, Vol. 70, No. 1, 1956, pp. 65-94. R. Solow: Technical Change and the Aggregate Production Function, in: Review of Economics and Statistics, Vol. 39, No. 3, 1957, pp. 312320. and capital? In other words, can the rate of interest as a price signal be negative? The elasticity of substitution between labour and capital, as defined by the Solow production function, is inadequate, because it presupposes that both factor prices (the wage rate and the rate of interest) are positive.

Using the much older concept of the 'period of production' $T$, as established by Böhm-Bawerk ${ }^{8}$ and modernised by Hicks, ${ }^{9}$ I develop an alternative parameter for the substitution between labour and capital, ${ }^{10}$ called the 'coefficient of intertemporal substitution'. It describes how the period of production changes upon a marginal change of the rate of interest. It is denoted by $\Psi$, and in the meta-model it is always non-negative. ${ }^{11}$ Moreover, it is well defined even for negative rates of interest.

Using $\Psi$, we see the meaning of the historical fact that the capital-output ratio has no trend despite a declining trend in the real rate of interest. The period of production $T$ is almost the same thing as the capital-output ratio. $T$ is the ratio between the stock of real capital and annual consumption in a steady state. It can be shown that a trendless $T$ implies that the value of $\Psi$ must be equal to or close to unity. This again implies that the OECD area plus China presently produce in a period of production $T$ so that a higher level of capital intensity would be counterproductive. It would reduce - rather than raise - net output per worker. The change (delta) in GDP would be outweighed by a change in depreciations.

\section{The end of capital scarcity?}

Up to a point, complexity of the production system is productive. Adam Smith taught us that the main source of wealth and welfare is the division of labour. ${ }^{12}$ And complexity is a byproduct of the division of labour. Yet, complexity has its costs, e.g. in the form of transaction costs or costs of incomplete information. Thus, it is plausible that some intermediate value of complexity maximises welfare. A higher degree of roundaboutness in production goes along with a higher degree of complexity. The period of production $T$ may then also maximise welfare at some finite level. The prevailing zero real rate of interest may be the price signal that this welfare maximising level of roundaboutness has now been reached. We may have outgrown the age of capital scarcity.

8 Böhm-Bawerk, op cit.

9 J. Hicks: Value and Capital, Oxford 1939, Clarendon Press.

10 C.C. von Weizsäcker, op. cit.

11 Ibid., see Theorem 6A.

12 A. Smith: An Inquiry into the Nature and Causes of the Wealth of Nations, London, Printed for W. Strahan and T. Cadell, in the Strand, 1776 . 
The conditions for full employment and price stability

According to Keynes, full employment requires that the plans and dispositions of the agents and the government sum up to an equal amount of savings and of net investments at full employment. This is an equation in terms of flow variables. For our purpose, we have to work with value stocks. If one divides the stocks by flows, we get coefficients with the time dimension. The period of production $T$ is the coefficient with the capital stock in the numerator and annual consumption in the denominator.

We can define a corresponding coefficient for the supply side of capital. We denote it by $Z$ and we call it the 'waiting period'. It is a weighted average of the waiting periods of the agents. The waiting period of an agent is the planned coefficient between the level of personal wealth and personal present annual consumption. It is, so to speak, the result of an agent's 'life plan'. The term waiting period $Z$ denotes the average time distance between the stream of consumption and the stream of earned income within the life span of the agent. Thus, if we assume a zero rate of interest and further assume that an agent plans to consume a constant value flow from age 20 to age 80 and plans to earn a constant flow of wages from age 20 to age 60 . The time distance between the time point of gravity of consumption levels (age 50) and the time point of gravity of wages (age 40) is ten years. Here $Z$ is 10 years. For an overlapping generations economy of agents of this type with a stationary population, one can show that the wealth-consumption ratio of this economy equals 10 years, i.e. equals $Z$.

Now I compare this planned waiting period with the actual ratio between private wealth and annual consumption. This ratio is given by the expression $T+L+D$, where $T$ is real capital, $L$ stands for land value and $D$ is net public debt, each in relation to annual consumption of the economy. Assume now that $T+$ $L+D$ is markedly lower than $Z$. This then means that the representative agent wants to reduce his/her consumption outlays in order to raise savings and thereby raise $T+L+D$. But this results in a slump away from full employment. Therefore, a condition for full employment is the inequality $T+L+D \geq Z$.

On the other hand, assume that the central bank pursues the goal of price stability. If $T+L+D$ were substantially above $Z$, inflation would loom. People would want to raise their consumption expenditure and reduce their savings, so that total demand would exceed total supply at full employment. Then the central bank would step in to discourage expenditures by raising the rate of interest. Thus, a situation of full employment combined with price stability is characterised by the approximate equation $Z \approx T+L+D$.

As described above for the OECD area plus China, we have estimates of $T, L$ and $D$. We can assume that fiscal policy of the states and monetary policy of central banks in this area aim at equating $T+L+D$ with $Z$. We therefore can assume that $Z$ is approximately equal to $T+L+D$.

\section{The Great Divergence: Secular growth of the waiting period Z}

The demographic forecasts of the United Nations predict a steady growth in life expectancy. While it is at 70 years today, life expectancy is predicted to rise to roughly 82 years by the year 2100. This amounts to an average growth rate per year of at least fifty days. ${ }^{13}$

The waiting period $Z$ is closely related to the life expectancy of the population. Using the simple numerical example from the preceding section, assume that the agent plans a constant value flow of consumption from age 20 to age 84 and a constant flow of wages from age 20 to age 60 . In this case, the waiting period $Z$ is $52-40=12$ years. Thus, in this very simple example the waiting period grows by half the growth rate of life expectancy. ${ }^{14}$

The example implies steady growth of the waiting period $Z$ in contrast to the almost stationary capital-output ratio and thus to the almost stationary period of production $T$. At present, $Z \approx T+L+D$ is already substantially larger than $T+L$. Furthermore, we can expect $Z-T$ - $L$ to grow steadily. This is what this article refers to as the Great Divergence between the private supply of capital and the private demand for capital. We can expect a steady growth of the full-employment compatible fiscal net indebtedness $D$. This is the great macroeconomic challenge of the future. As space does not permit an exhaustive consideration of this challenge, let us focus two important question: Can we save free international trade? And, closely related, can we save the euro?

\section{The danger of protectionism}

In previous periods of real and nominal rates of interest clearly above zero, the world could hope to function with flexible exchange rates, as suggested by Milton Friedman 70 years ago. He imagined the macroeconomic autonomy of states concerning their central bank policy, ideally, in a world of free trade. If cyclical problems of effective demand and supply occured, the national central bank could lower or raise the central bank lending rate and thereby remedy these problems. After the breakdown of the Bretton Woods System in the early 1970s, a system prevailed which came closer to a regime of

13 United Nations, Department of Economic and Social Affairs, Population Division: World Population Prospects: the 2017 Revision, Key Findings and Advanced Tables, ESA/P/WP/248, NY: United Nations.

14 This $50 \%$ relation is quite typical but it is more nuanced than this simple example reveals. 
flexible exchange rates. That world, gone by now, is what can be called a 'Friedman world'.15

Our present world is different: let us call it the 'Keynes world'. Central banks are no longer able to set lending rates in such a way as to always obtain the optimal compromise between the imminent risks of deflation and inflation. Central bankers are tempted to call on fiscal authorities for a more expansionary fiscal policy. In the Friedman world, it was the other way round: central bankers admonished authorities for shying away from high government deficits. Yet, today the zero lower bound is binding.

In the Friedman world, capital was scarce. Its price, the rate of interest, was positive. Today, however, capital abounds. The binding zero lower bound speaks to this abundance. The new world of capital abundance also changes the politics of international trade. Free trade is easier to accomplish under capital scarcity. If incremental public debt's impact on interest rates tends to crowd out private investments, more inflows of capital via import surpluses may be a welcome alternative to domestic crowding-out of private investments. Protectionist moves may be countered by reference to the conundrum of capital scarcity. In a world in which unilateral imposition of trade barriers are a looming possibility, capital scarcity may nevertheless imply that free trade is a kind of Nash equilibrium.

This is different in the Keynes world of capital abundance. People, i.e. voters, have much more concern for their jobs because they understand that an important policy parameter is no longer available. The risk of a recession or depression is then more acute. The fear that imported goods may replace locally produced goods is much higher and protectionism may become much stronger.

This is particularly true in countries with a balance of payments deficit. The election of Donald Trump with his campaign against free trade is the result of increasing protectionist sentiments; and this is due, in turn, to the end of capital scarcity. Free trade, then, is no longer a Nash equilibrium. A country with a trade deficit may believe that jobs are unjustly distributed internationally. Coupled with a particularly heavy influence in international trade negotiations, this country is likely to favour a particularly aggressive stance.

\section{The 'New Trade Policy'}

The Keynes world of capital abundance induces a 'New Trade Policy'. Trump's election and perhaps reelection is not an accident, but rather a derivative of the Keynes world. The rules

\footnotetext{
15 M. Friedman: The Case for Flexible Exchange Rates, in: M. Fried man: Essays in Positive Economics, 1953, pp. 157-203, University of Chicago Press.
}

of the WTO are likely to be too weak to prevent a wave of protectionism.

In the Keynes world, i.e. under the regime of the New Trade Policy, access to a nation's domestic market is the most important diplomatic asset in trade negotiations. The larger that domestic market is, the heavier its influence. And a negative trade balance creates a formidable advantage in trade negotiations. Donald Trump plays an aggressive trade game by exploiting the negotiating strength of the US.

\section{Optimal rate of interest and free trade}

Free trade can be made a more stable regime through the introduction of a system of rules that link fiscal policy and trade balances in a certain way. It is assumed that the international agreement has decided that the optimal risk-free real rate of interest $r^{*}$ is, e.g. one percent per annum. It cannot be much higher because of the high level of public debt under full employment.

If the actual rate $r$ is below $r^{\star}$, then a member country shoulders the obligation. If it shows an export surplus, it is obliged to reduce this surplus by aiming at a fiscal deficit $f\left[\left(r^{\star}-r\right), s\right]$, where $s$ is the trade surplus as a share of national income. If it shows a trade deficit, it incurs no obligation. By this rule, one hopes that the trade surplus declines while the real rate of interest in the world capital market increases simultaneously. In this case, for example, Germany would have to incur public debt. This would definitely raise the rates of interest in the world capital market.

If the actual real rate $r$ is above the optimal rate, then countries with a trade deficit are obliged to reduce their fiscal deficit - thereby contributing to a reduction in the trade deficit by means of a contractionary fiscal policy. This has a lowering impact on the rate of interest in the world capital market.

We should note that the national obligations under such a regime are easy to bear because, regardless of its effect on stabilising a free trade regime, it is in the national interest to raise public debt when interest rates are low and to reduce it when interest rates are high. If such an agreement is in place, the just international distribution of jobs should become less of an issue for protectionists.

\section{Stabilising the euro: Trade balances and public debt}

This agreement should be applied to the national trade balances of the states in the eurozone. The surplus of private savings over private investment is particularly large in Europe. Thus, despite the implicit public debt of the social security system, a country like Germany now exhibits a trade surplus that is larger than private household savings. Even a country 
like Italy with substantial net additions to explicit public debt has a trade surplus. The southern part of the eurozone does not have full employment. A eurozone with full employment in each country should have a substantial trade surplus - perhaps in a percentage range similar to that of Germany.

But such a trade surplus is not feasible. Even without Trump's trade policy, it would not come about because the euro would strongly appreciate as it approached full employment due to increased trade surpluses. This, in turn, would further halt any increase in the trade surplus long before full employment would be achieved.

Moreover, there is the New Trade Policy of the Keynes World. The US, and probably, Asian countries, in particular China, would take measures that would make things difficult for European exporters. Regardless, the European Central Bank would not counteract the rise of the euro against the dollar by buying dollars en masse. The rest of the world, particularly the US, would employ strong countermeasures, such as raising import tariffs.
Thus, at the present level of public debt in the eurozone, the euro is unfit to generate universal full employment. This may create a rising sentiment among the electorate in countries like Italy for an 'Italexit'.

Only by raising the level of public debt in the northern EU Member States can the national governments stabilise the euro. And only at this time will the common currency of the EU become compatible with full employment in the euro area.

In the world of the New Trade Policy, domestic demand must suffice to generate full employment if the sentiment of the just international distribution of jobs is to be politically compatible with free trade.

Capital abundance changes the rules of macroeconomic policy. The main cause of capital abundance is the high life expectancy of the people in the OECD area and China. A high level of net public debt is required for full employment under this condition. Many unsettled policy issues arise out of capital abundance. 